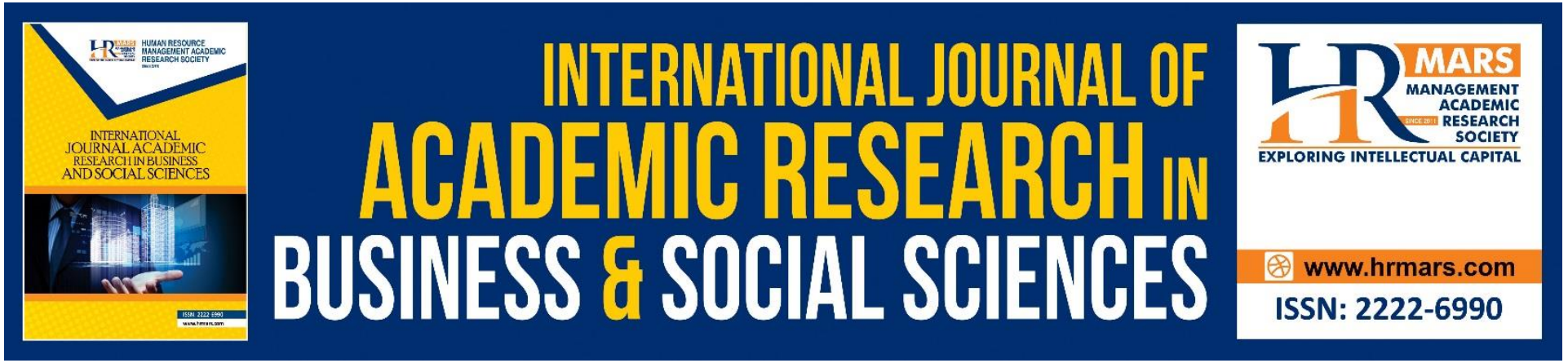

\title{
The Relationship between Liquidity Ratios and EPS
}

\author{
Mary Mathews, Siti Nurbaayah Daud, Dihlvinder Kaur Gill
}

To Link this Article: http://dx.doi.org/10.6007/IJARBSS/v11-i8/10841 DOI:10.6007/IJARBSS/v11-i8/10841

Received: 17 June 2021, Revised: 24 July 2021, Accepted: 05 August 2021

Published Online: 26 August 2021

In-Text Citation: (Mathews et al., 2021)

To Cite this Article: Mathews, M., Daud, S. N., \& Gill, D. K. (2021). The Relationship between Liquidity Ratios and EPS. International Journal of Academic Research in Business and Social Sciences, 11(8), 1450-1457.

Copyright: (c) 2021 The Author(s)

Published by Human Resource Management Academic Research Society (www.hrmars.com)

This article is published under the Creative Commons Attribution (CC BY 4.0) license. Anyone may reproduce, distribute, translate and create derivative works of this article (for both commercial and non-commercial purposes), subject to full attribution to the original publication and authors. The full terms of this license may be seen at: $\underline{\text { http://creativecommons.org/licences/by/4.0/legalcode }}$

Vol. 11, No. 8, 2021, Pg. 1450 - 1457

http://hrmars.com/index.php/pages/detail/IJARBSS

JOURNAL HOMEPAGE

Full Terms \& Conditions of access and use can be found at

http://hrmars.com/index.php/pages/detail/publication-ethics 


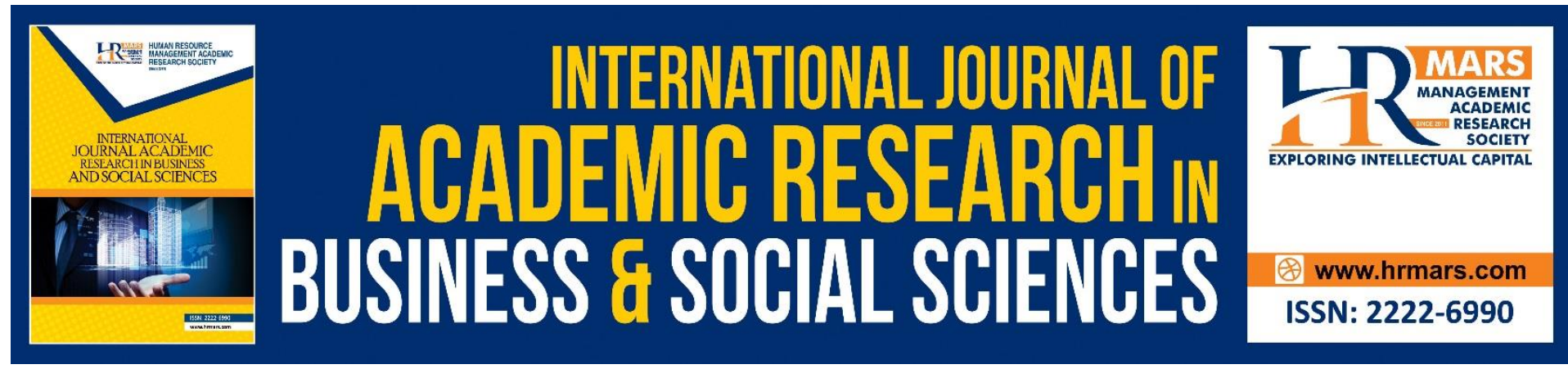

\title{
The Relationship between Liquidity Ratios and EPS
}

\author{
Mary Mathews, Siti Nurbaayah Daud, Dihlvinder Kaur Gill \\ Inti International University Persiaran Perdana BBN, Putra Nilai, 71800 Nilai, Negeri \\ Sembilan, Malaysia \\ Email: mary.kamathew@newinti.edu.my, sitinurbaayah.daud@newinti.edu.my, \\ dihlvinder.kgill@newinti.edu.my
}

\begin{abstract}
The objectives of the study were to calculate and measure liquidity ratios and EPS ratios of public listed companies and to examine the relationship between the liquidity ratios and EPS ratios. The study was empirical in nature. The study was conducted over a period of 5 years for the financial years 2015 to 2019 . The study was based on secondary sources of data. Ratios were calculated from the information given in the balance sheet of the companies. Regression was applied to check the relationship between EPS and 3 liquidity ratios. It was concluded that cash ratio has the most influence over EPS compared to current ratio and acid test.
\end{abstract}

Keywords: Ratio, EPS, Liquidity

\section{Introduction}

Liquidity shows the company's ability to pay off or settle its short-term creditors. Liquidity is measured as one of the debt ratios, which is a ratio that measures the percentage of capital requirements spent on debt (Brigham and Houston, 2006). In accordance with the pecking order theory, companies generally prefer using their own funds. Companies with high liquidity would reduce their external funding because the source of their internal funds is high. Extensive research has been done to analyse profitability and capital structure to earnings per share (EPS). The aim of this paper is to analyze the direct influence of liquidity ratios (current ratio, quick ratio and cash ratio) on EPS. The objectives of this study are:

1. To calculate and measure liquidity ratios of eight public listed companies.

2. To calculate and measure EPS ratios of eight public listed companies.

3. To examine the relationship between liquidity ratios and EPS ratios.

\section{Literature Review}

Changes in earnings normally used as a tool for evaluating the efficiency of the company's business operations. Normally, it is difficult to predict the future profits of the business. Although management cannot promise the exact amount of profit, they can however estimate how much profit will be gained in the coming year. EPS is a ratio calculated and used by investors to decide whether to purchase, sell or retain their investment in shares. EPS is the percentage of a corporation's profit which is assigned to each individual stock share. It is 
a concept that is of great importance to investors and people who trade in the stock market. The greater a company's earnings per share, the higher its profitability would be (The Ecomonic Times, 2020)

$$
\text { Earnings per share }=\frac{\text { Earnings after tax }}{\text { No of shares outstanding }}
$$

The study (Hamshari, 2020) indicated that there is a direct relationship between the operating cash flows and the return on the stock, and that there are some activities that affect the earnings per share positively. The study recommended that investors and users should focus on data related to cash flows, especially operational cash flows because of its impact on determining the earnings per share and is considered one of the indicators of important financial performance.

The liquidity ratio is a ratio which describes the ability of the company to meet shortterm obligations. The definition of 'liquidity' is used to address the company's financial situation. In accordance with Kasmir (2012), the purpose of such ratio is to illustrate or calculate the ability of the company to satisfy due obligations, both to parties outside the company and within the company (as cited in Baraja \& Yosya, 2018).

A study was conducted on five companies, in the manufacturing industry and listed in the Jakarta Islamic Index (JII), in the period 2012 - 2016, to determine the relationship between current ratio, EPS and debt to equity ratio. The companies have been selected by way of non-probability sampling technique. The results showed that current ratio does not directly affect earnings per share but current ratio has a direct effect on debt to equity ratio (Darto, 2019).

There are several ratios of liquidity that will be used in this analysis, namely:

a. Current Ratio, a ratio which is the capacity to pay obligations that must be met immediately with current assets, deriving through comparison between the current assets and current liabilities.

$$
\text { Current Ratio }=\frac{\text { Current Assets }}{\text { Current Liabilities }}
$$

b. Quick Ratio, a ratio that measures assets that are truly liquid only, i.e., current noninventory or inventory-reduced assets, relative to current debt. This ratio is a calculating instrument to illustrate the capacity of a company to pay obligations that must be met with more liquid current assets immediately.

$$
\text { Quick Ratio }=\frac{\text { Current Assets-Inventories }}{\text { Current Liabilities }}
$$

c. Cash Ratio, a ratio which is the result of short-term liabilities divided by cash and cash equivalent. The cash ratio is used to calculate the appropriateness of the money available in a corporation to pay off short-term debt obligations (Fakhrun et al., 2019).

$$
\text { Cash Ratio }=\frac{\text { Cash and Cash Equivalents }}{\text { Current Liabilities }}
$$




\section{Research Hypotheses}

The purpose of this study is to investigate the relationship between earnings per share and liquidity of the companies.

Therefore, according to the purpose of the study, the following research hypotheses underpin the study:

$H_{0}: \beta_{1}=\beta_{2}=\beta_{3}=0$

Null hypothesis, there is no statistically significant difference or relationship between variables.

Ha: "at least one of the $\beta$ is not equal to 0 "

The alternative hypothesis $(\mathrm{Ha})$ states that there is a statistically significant difference or relationship between variables.

\section{Methodology \\ Data Collection}

The present study is conducted over a period of five years from 2015 to 2019. The study is based on secondary data. The main source of data supporting the research work is annual financial report of eight public listed companies, selected at random. It is assumed that different currencies will not affect the final outcome of the study.

\section{TOOLS USED: Regression by excel}

Main data for this study are eight annual financial reports of public listed companies for five consecutive years from 2015 to 2019.

The data retrieved from the annual financial reports of eight companies to perform ratio analysis is reflected below.

Figure 1 - Padini

\begin{tabular}{|l|c|c|c|c|c|}
\hline Year (Y) & Y 2015 & Y 2016 & Y 2017 & Y 2018 & Y 2019 \\
\hline EPS (RM) & $\mathbf{1 2 . 1 9}$ & $\mathbf{2 0 . 8 8}$ & $\mathbf{2 3 . 9 2}$ & $\mathbf{2 7 . 0 8}$ & $\mathbf{2 4 . 3 4}$ \\
\hline Current Ratio & $2.64: 1$ & $2.12: 1$ & $2.33: 1$ & $2.93: 1$ & $3.92: 1$ \\
\hline Acid-test ratio & $1.69: 1$ & $1.28: 1$ & $1.71: 1$ & $1.94: 1$ & $2.58: 1$ \\
\hline Cash Ratio & $0.78: 1$ & $0.76: 1$ & $1.34: 1$ & $1.72: 1$ & $2.29: 1$ \\
\hline
\end{tabular}

Figure 2 - Maxis

\begin{tabular}{|l|c|c|c|c|c|}
\hline Year & Y 2015 & Y 2016 & Y 2017 & Y 2018 & Y 2019 \\
\hline EPS (RM) & $0.23 /$ share & $0.27 /$ share & $0.28 /$ share & $0.23 /$ share & $0.19 /$ share \\
\hline Current Ratio & $0.59: 1$ & $0.50: 1$ & $0.63: 1$ & $0.59: 1$ & $0.51: 1$ \\
\hline Acid-test ratio & $0.58: 1$ & $0.50: 1$ & $0.63: 1$ & $0.58: 1$ & $0.51: 1$ \\
\hline Cash Ratio & 0.31 & 0.17 & 0.15 & 0.12 & 0.10 \\
\hline
\end{tabular}

Figure 3 - Ajinamoto

\begin{tabular}{|l|c|c|c|c|c|}
\hline Year & Y 2015 & Y 2016 & Y 2017 & Y 2018 & Y 2019 \\
\hline EPS (RM) & 0.489 & 0.671 & 3.083 & 0.925 & 0.931 \\
\hline Current Ratio & $5.40: 1$ & $5.55: 1$ & $9.74: 1$ & $10.70: 1$ & $8.12: 1$ \\
\hline Acid-test ratio & $3.89: 1$ & $4.41: 1$ & $8.39: 1$ & $9.48: 1$ & $7.33: 1$ \\
\hline Cash Ratio & 2.95 & 3.47 & 2.89 & 3.38 & 1.89 \\
\hline
\end{tabular}


INTERNATIONAL JOURNAL OF ACADEMIC RESEARCH IN BUSINESS AND SOCIAL SCIENCES Vol. 11, No. 8, 2021, E-ISSN: 2222-6990 @ 2021 HRMARS

Figure 4 - Kellogg Company

\begin{tabular}{|l|r|r|r|r|r|} 
Year & Y 2015 & Y 2016 & Y 2017 & Y 2018 & Y 2019 \\
\hline Current ratio & 0.72 & 0.51 & 0.67 & 0.70 & 0.72 \\
\hline Acid test & 0.44 & 0.30 & 0.40 & 0.40 & 0.46 \\
\hline cash ratio & 0.06 & 0.05 & 0.06 & 0.07 & 0.08 \\
\hline EPS (\$) & 1.74 & 1.98 & 3.61 & 3.85 & 2.81 \\
\hline
\end{tabular}

Figure 5 - Pepsi Company

\begin{tabular}{|l|r|r|r|r|r|} 
Year & Y 2015 & Y 2016 & Y 2017 & Y 2018 & Y 2019 \\
\hline Current ratio & 1.31 & 1.28 & 1.51 & 0.99 & 0.86 \\
\hline Acid test & 1.16 & 1.15 & 1.37 & 0.85 & 0.70 \\
\hline cash ratio & 0.52 & 0.43 & 0.52 & 0.39 & 0.27 \\
\hline EPS (\$) & 3.71 & 4.39 & 3.4 & 8.84 & 5.23 \\
\hline
\end{tabular}

Figure 6 - General Mills

\begin{tabular}{|l|r|r|r|r|r|}
\hline Year (Y) & Y 2015 & Y 2016 & Y 2017 & Y 2018 & Y 2019 \\
\hline Current ratio & 0.754 & 0.785 & 0.762 & 0.562 & 0.591 \\
\hline acid test ratio & 0.439 & 0.503 & 0.483 & 0.338 & 0.371 \\
\hline cash ratio & 0.068 & 0.152 & 0.144 & 0.054 & 0.063 \\
\hline EPS (\$) & 2.02 & 2.83 & 2.82 & 3.69 & 2.92 \\
\hline
\end{tabular}

Figure 7 - Kawan Food Bhd

\begin{tabular}{|l|r|r|r|r|r|}
\hline Year & Y 2015 & Y 2016 & Y 2017 & Y 2018 & Y 2019 \\
\hline Current ratio & 3.661 & 3.601 & 3.170 & 3.439 & 3.199 \\
\hline acid test ratio & 3.361 & 3.278 & 2.802 & 2.802 & 2.626 \\
\hline cash ratio & 2.568 & 1.574 & 1.518 & 1.072 & 1.179 \\
\hline EPS (RM) & 2.02 & 2.83 & 2.82 & 3.69 & 2.92 \\
\hline
\end{tabular}

Figure 8 - Apollo Food Holdings

\begin{tabular}{|l|r|r|r|r|r|}
\hline Year (Y) & Y 2015 & Y 2016 & Y 2017 & Y 2018 & Y 2019 \\
\hline Current ratio & 12.544 & 13.556 & 15.589 & 17.858 & 15.713 \\
\hline acid test ratio & 10.865 & 12.041 & 14.039 & 15.996 & 14.107 \\
\hline cash ratio & 7.732 & 8.966 & 10.031 & 9.342 & 10.640 \\
\hline EPS (RM) & 31.62 & 37.18 & 22.29 & 13.84 & 21.78 \\
\hline
\end{tabular}




\section{Results}

\begin{tabular}{lr}
\hline \multicolumn{2}{c}{ Regression Statistics } \\
\hline Multiple R & 0.752320038 \\
R Square & 0.56598544 \\
Adjusted R & \\
Square & 0.52981756 \\
Standard & \\
Error & 6.841334198 \\
Observations & 40 \\
\hline
\end{tabular}

ANOVA

\begin{tabular}{lrrrrr}
\hline & & & & & \multicolumn{2}{c}{ Significance } \\
& $d f$ & & \multicolumn{1}{c}{ SS } & MS & \multicolumn{1}{c}{$F$} \\
\hline Regression & 3 & 2197.278333 & 732.4261 & 15.64884 & $1.11937 \mathrm{E}-$ \\
Residual & 36 & 1684.93873 & 46.80385 & & \\
Total & 39 & 3882.217063 & & & \\
\hline
\end{tabular}

\begin{tabular}{lrrrrrr}
\hline & Coefficients & \multicolumn{2}{c}{ Standard } & & & \\
& Error & $t$ Stat & P-value & Lower 95\% & Upper 95\% \\
\hline Intercept & 5.90193474 & 1.39819090 & 4.22112 & 0.00015 & 3.06627216 & 8.7375973 \\
& 3 & 1 & 2 & 7 & 4 & 2 \\
Current & 0.12001636 & 0.06902292 & & 0.09061 & 0.01996861 & 0.2600013 \\
ratio & 1 & 3 & 1.73879 & 8 & 4 & 4 \\
& - & & & & - & \\
Acid test & 2.49840818 & 0.84896351 & - & & 4.22018598 & - \\
ratio & 3 & 2 & 2.94289 & 0.00566 & 8 & 0.7766304 \\
& & 1.29936123 & 4.01393 & 0.00028 & 2.58032806 & \\
Cash ratio & 5.21555478 & 1 & 8 & 9 & 1 & 7.8507815 \\
\hline
\end{tabular}

\section{Discussion}

Regression analysis has been used to quantify the relationship between the liquidity ratios and EPS.

$H_{0}: \beta_{1}=\beta_{2}=\beta_{3}=0$

Null hypothesis, there is no statistically significant difference or relationship between variables.

$\mathrm{Ha}$ : " at least one of the $\beta$ is not equal to 0 "

The alternative hypothesis $(\mathrm{Ha})$ states that there is a statistically significant difference or relationship between variables

1. Since the $p$-value $=1.119373 \times 10^{-6}<0.05$, we conclude that the regression model is a significantly good fit, yielding evidence that the independent variables have a significant impact on the dependent variables.

2. We reject the null hypothesis

3. Note that the $p$-value for the coefficient of acid test and cash ratio is lower than 0.05 . 
4. $p$-value for the coefficient of current ratio is higher than 0.05 , which indicates that it is not statistically significant.

5. Adjusted R-square of 0.5298 , adjusted for degree of freedom, means that $53 \%$ of the variation in $Y$, EPS, can be explained by variations in $X_{1}, X_{2}$ and $X_{3}$, Current ratio, acid test and cash ratio. This is in line with many theories that state that EPS is also influenced by the condition of the economy.

6. Looking at the coefficients, we see that cash ratio has the most positive impact on EPS, this is in line with the theory that states, there is a clear relationship between the cash flows and earnings per share (Ahsan Habib, 2010).

7. Current ratio has a low impact on EPS and acid test has a negative impact on EPS. This is in line with the findings by Riyanti Darto (Darto, 2019)

8. A negative coefficient suggests that as the independent variable increases, the dependent variable tends to decrease.

\section{Conclusion and Recommendations}

Ratio analysis is a valuable tool, often used in providing insights into a company's financial picture. The major findings from this study are that, of the three liquidity ratios (current ratio, acid test ratio and cash ratio) cash ratio has the most influence on EPS, followed by current ratio and acid test ratio. We can conclude that, availability of cash is the main determining factor for payment of EPS, compared to any other current assets.

Cash ratio is much more restrictive than current ratio or quick ratio because no other current assets can be used to make payment but only cash. In short, it is purer liquid than quick and current ratio (Cash Ratio or Cash Coverage Ratio (CCR), 2019).

Inventory is also a determining factor in paying out EPS. We see that coefficient of current ratio is positive but when we remove the inventory from current assets (acid test), the coefficient becomes negative.

EPS is one of the ratios investors would seriously consider before making any investment decisions and all public listed companies are required to calculate and present their EPS in their financial statement (Melville, 2019). Inventories are a major part of a company's current assets.

I would recommend that further studies need to be done to determine, the impact of inventories on companies' EPS.

\section{References}

Ahsan Habib, F. H. (2010). Performance evaluation and ratio analysis of Pharmaceutical Company in Bangladesh. Master"s Thesis in International Business 15 ECTS Department of Economic and Informatics University West. Published. http://www.diva-portal.org/smash/get/diva2:323754/fulltext01

Ajinomoto (Malaysia) Berhad. (2015-2019). Annual report. https://www.ajinomoto.com.my/investors/annual-reports

Apollo Food Holdings Berhad. (2015-2019). Annual report. https://www.apolloic.com/shareholders/annual-report

Baraja, L. U., \& Yosya, E. K. A. (2018). The Impact of Liquidity, Profitability, Activity and Solvency Ratio on Change in Earnings. Indonesian Management and Accounting Research, 17(1). https://www.researchgate.net/publication/335344270_Analysis_the_Impact_of_Liq uidity_Profitability_Activity_and_Solvency_Ratio_on_Change_in_Earnings 
Cash Ratio or Cash Coverage Ratio (CCR). (2019). Ratiosys. https://ratiosys.com/cash-ratio-or-cash-coverage-ratio-ccr/

Darto, R. (2019). The Effect of Liquidity, Profitability and Size Ratios on Capital Structure and Implications for the Value of Manufacturing Industry CompaniesListed on the IDX. KnE Social Sciences. Published. https://knepublishing.com/index.php/KnESocial/article/view/5419/10689

Fakhrun, A., Bambang, S., \& Ary, Y. (2018). The impact of cash ratio, debt to equity ratio, receivables turnover, net profit margin, return on equity, and institutional ownership to dividend payout ratio'. Journal of Research in Management, 1(4), 1-11.

Hamshari, Y. M. A. (2020). The Effect of the Relationship Between Cash Flows From Operating Activities and Earnings per Share in Jordan. The Effect of the Relationship Between Cash Flows From Operating Activities and Earnings per Share in Jordan, 11(4). https://www.researchgate.net/publication/342779472_The_Effect_of_the_Relation ship_Between_Cash_Flows_From_Operating_Activities_and_Earnings_per_Share_in _Jordan

Kellogg Company. (2015-2019). Annual report. https://www.annualreports.com/Company/kellogg-company

Kawan Food Berhad. (2015-2019). Annual report. https://www.klsescreener.com/v2/announcements/view/3165687

Maxis. (2015-2019). Annual report. https://maxis.listedcompany.com/download.html

Melville, A. (2019). Ratio Analysis. In International Financial Reporting A Practical Guide (7th ed., pp. 361-380). Pearson.

Padini Holdings Bhd. (2015-2019). Annual report. https://corporate.padini.com/investor-relations/

Pepsico. (2015-2019). Annual report. https://www.pepsico.com/investors/financial-information/annual-reports-andproxy-information

The Ecomonic Times. (2020). Definition of 'Earnings Per Share (eps). https://economictimes.indiatimes.com/definition/earnings-per-share-eps 